\title{
PROCEEIINGS
}

OF THE

\section{UNITED STATES NATIONAL MUSEUM}

FOR THE YEAR 1890.

VoLUMe XIII.

DESCRIPTION OF A NEW SPECIES OF LAND SHELL FROM CUBAVERTIGO CUBANA.

LY

WM. H. Dall, Curator of the Depatment of Mollusks.

Vertigo cubana sp. nov.

Testa parra, dextrorsa, rubescente castanea, a pice pallida, obtusa ; anfr. $\mathrm{v}$ convexi, superficies spiraliter striatula, costulis transversis flex. uosis ad $\mathrm{xxv}$, concinne clathrati ; basis imperforata ; apertura campa. nulata, trilobata, obliqua; singulis dentibus in margine dextro et in basali, duobus in pariete aperturali; $\max$ alt. .07; max. lat. 055 poll.

Shell pinkish brown, paler toward the apex, small, short, stont, dextral, five-whorled; apex rather bluntly rounded, sides subparallel, base full and rounded; spiral sculpture of fine striæ, most prominent between the ribs on the last whorl and obsolete on the early whorls; they do not overrun the ribs; transverse sculpture of (on the last whorl about: twenty-five) strong, sigmoid, squarish, narrow, elevated ribs, running from suture to suture, and separated by much wider interspaces; these ribs are closer and finer toward the apex of the spire, they resemble when best developed those of Pupa lyrata Gould; last whorl subconstricted before the aperture is formed; aperture obscurely trilo. bate, margin well reflected, whitish ; primary lamellæ, except $\mathrm{A}$ and $\mathrm{E}$, set rather more deeply in the throat than usual. Formula A C E according to Dr. Sterki's arrangement. The primary A is stronger and more triangular at the aperture than the others, but becomes a thin, narrow, sharp lamella internally; the secondary, 2, does not come so near the aperture as A, but further back is a little higher than. the lat-

Proc. N. M. $90-1$ 
ter, and the two run parallel like rails on a track, but somewhat irregularly. From the aperture no lamella can be observed on the pillar, but the primary $\mathbf{C}$, which falls short of reaching the margin and is comparatively weak toward the aperture, in the depths of the throat is higher aud stronger, forming a prominent, high, thin lamella. The primary $\mathrm{E}$ is prominent at the angle of the outer lip, and projects toward $\mathrm{A}$; deeper in it becomes lower and weaker, and still further in it projects in a high triaugular plate stronger than any of the others at that depth. There are no indications of any other lamellæ or callosities. The margin of the aperture is set somewhat obliquely to the axis (see Fig. 2). Max. lon. of shell, 1.75; max. diam., $1.37^{\mathrm{mm}}$.

Hавітат.-Cuba.

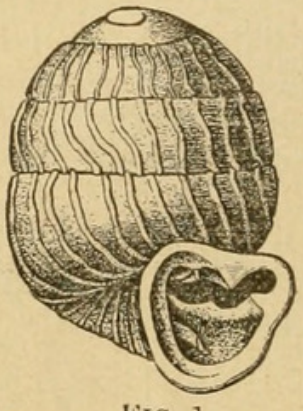

FIG. 1.

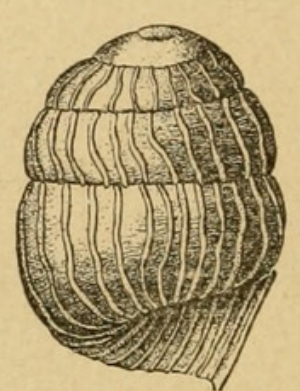

FIG. 2.

Fig. 1.-Vertigo cubana Dall, type specimen magnified seventeen diameters, front view.

Fig. 2.-The same, viewed from the side to show obliquity of the margin of the aperture.

A single specimen of this remarkable little species is in the U. S. National Museum, mollusk register 87645 . It was received from the collection of the late Dr. Shurtleff, now belonging to Wesleyan University, Middietown, Conn., and was obtained by him from the late Prof. C. B. Adams, or at least still occupies the tiny glass tube, stopped with sealing-wax, in which Professor Adams secured his minutiæ, and a tiny label on which is written "Pupa .... Cuba" in Professor Adams's wellknow chirography. The only species resembliug this to my knowledge is Pupa lyrata Gould, a native of the Sandwich Islands, which is sinistral and much larger, measuring $2.75^{\mathrm{mm}}$ in length. P. lyrata has a distinct though feeble colnmellar plait or ridge, and it is possible that a more advanced specimen of the Cuban species might possess it, yet the shell appears perfectly mature. The Cuban shell has the transverse ribs strongest on the last whorl, while in $P$. lyrata they are strongest on the upper part of the spire. Notwithstanding these differences these two species evidently belong to the same section of the genus. P. $l y$ rata is referred to Vertigo by Gould in the "Otia," and Pfeiffer places it in the section Vertilla Moquin Tandon, characterized by some peculiarities of the jaw and by a reversed shell, the latter a character of no value. For the present, until the sections of Vertigo are more definitely established, it will be sufficient for all purposes to leave our Cuban species under that head without attempting a more precise classification. 


\section{$2 \mathrm{BHL}$ Biodiversity Heritage Library}

1890. "Description of a new species of land shell from Cuba.Vertigo cubana." Proceedings of the United States National Museum 13, 1-2.

View This Item Online: https://www.biodiversitylibrary.org/item/53445

Permalink: https://www.biodiversitylibrary.org/partpdf/52019

\section{Holding Institution}

Smithsonian Libraries

\section{Sponsored by}

Smithsonian

\section{Copyright \& Reuse}

Copyright Status: Public domain. The BHL considers that this work is no longer under copyright protection.

This document was created from content at the Biodiversity Heritage Library, the world's largest open access digital library for biodiversity literature and archives. Visit BHL at https://www.biodiversitylibrary.org. 